\title{
School Plant Planning as Correlate of Students' Academic Performance in Southwest Nigeria Secondary Schools
}

\author{
Odufowokan Benard Adesina \\ Head of Department, General Studies Education, Tai Solarin College of Education \\ Omu-Ijebu, Ogun-State, Nigeria \\ E-mail: adesinaodufowokan@yahoo.com
}

Received: March 23, $2011 \quad$ Accepted: April 28, $2011 \quad$ doi:10.5430/ijba.v2n2p41

\begin{abstract}
This study among other things examines the relationship between school plant planning and students' academic performance in south west Nigeria secondary schools using descriptive survey research design. The sample consists of 1650 respondents comprising 150 school principals and 1500 students. Multistage, stratified and simple random sampling techniques were used to select the sample. Data collected were analyzed using frequency counts, percentages, means and Pearson product moment correlation. Five null hypotheses were tested at 0.05 level of significance. The study revealed that the levels of school plant planning and students` academic performance were relatively close, and as such students` academic performance was significantly related to instructional space planning, Administrative space planning, circulation space planning, planning for accessories and space for convenience planning. Based on the findings, it was recommended that authorities concerned should implement architectural designs of buildings and spaces for education to ensure students` academic performance.
\end{abstract}

Keywords: School, Plant, Planning, Correlate, Student, Academic, Performance, Nigeria

\section{Introduction}

It has been observed that adequate attention is now being paid to school plant planning throughout the world's educational systems including Nigeria. Educational facilities such as school plant have been repeatedly found to have positive relationship with standard and quality of educational system. (Nwagwu, 1978; Adesina, 1990; Ojedele, 2000). Nigeria as a nation strives to experience real growth and development. This requires a clearly defined development strategy that allows intensive utilization of resources which is endowed. These resources are the various school physical facilities that are indispensable in the educational process. They include the sitting, the building and physical equipment, recreation places for the achievement of educational objectives (Adepoju, 1998; Oluchuckwu, 2000).

School plant planning which include instructional spaces planning, administrative places planning, circulation spaces planning, spaces for conveniences planning and accessories planning are essential In teaching-learning process. The extent to which these spaces could enhance teaching and learning depends on their location within the school compound, their structure, and accessories. It is believed that a well planned school plant will gear up expected outcomes of education that will facilitate good social, political and economic emancipation, effective teaching and learning process and academic performance of the students.

Emphasizing the importance of school plant planning to students academic performance (Oluchukwu, 2000), asserted school plant planning as an essential aspect of educational planning, he went further to explain that "unless schools are well suited, buildings adequately constructed and equipment adequately utilized and maintained, much teaching and learning may not take place.

Corroborating these, Mark (2002) and Ajayi (2007), maintained that high levels of students' academic performance may not be guaranteed where instructional space such as classrooms, libraries, technical workshops and laboratories are structurally defective. They also emphasized that structural effectiveness, proper ventilation and well sited instructional space lead to successful teaching and learning process in Nigeria secondary schools.

Relating this study to international occurrences are the assertions of Williams, Persaud, and Turner (2008), quoting Marsden (2005), which reported that safe and orderly classroom environment (aspect of instructional space), School facilities (accessories) were significantly related to students' academic performance in elementary schools. The three researchers, also quoted Glassman (1994), asserting that a comfortable and caring environment among other treatments helped to contribute to students` academic performance. 
Supporting these findings are Duncanson and Achilles (2008), who affirmed teachers and the physical environment (plant space) are two major tools that can bring about new outcomes. They also Quoted Summer (1977), to have submitted that unintentionally and non-verbally, teachers expose their educational philosophy in the way they use space. Summarily, a study carried out by Lackney and Jacob (2002, p.1) stated that "it is difficult, if not impossible, to separate, instructional activity from the physical environment setting within which it occurs."

In south west Nigeria secondary schools, students' academic performance is poor generally going by existing records. Dada (1987), Enaesator (1995), Ajayi (1999), and Akibuiro and Joshua (2004) posited that there was persistent mass failure of students in the senior certificate examination (SSCE) conducted by the West African Examination Council (WAEC). Accordingly, Ajayi and Yusuf (2009), asserted that the observed poor academic performance of the secondary school students in south west Nigeria may not be unconnected with seemingly poor school plant planning in the schools. Contextually in this study, school plant planning refers to the following:

(i) Instructional Spaces: These include classrooms, auditorium, gymnasium, library, workshops, laboratory, arts room, home economics rooms, multipurpose rooms/halls, music area and any other space where students receive instruction.

(ii) Administrative Spaces: These comprise principal's office, clerk's office, staff room, Guidance Counselors' office and Health clinics.

(iii) Circulation Spaces: These include corridors, lobby, staircases and other spaces where students recreate.

(iv) Spaces for conveniences: These consist of toilets, cafeteria, kitchen dormitories custodian sheds and stores, and

(v) Accessories: These include parks, garden, fields, courts and lawns.

Essentially, Olagboye (1998) affirmed that the school plant consists of the basic systems and structures which a viable school or institution needs in order to function effectively and to fulfill the purpose for which it was established. In south west Nigeria secondary schools, instructional space such as classrooms, libraries, technical workshops and laboratories are structurally defective, that is, classrooms are not spacious enough. There are inadequate ventilation and lighting, classrooms located very close to technical workshops and main road. There are inadequacies in laboratory equipment and workshops while furniture, fittings and tools are not provided. These inadequacies may not make teaching and learning conducive, hence good academic performance of the students will be jeopardized. Odufowokan (2008), asserts "the planning, design and execution of a school building should take into consideration the total space available to it. Most modern schools within the urban areas have limited space for accommodations, hence the reason for two, three storey buildings within their compound." Accordingly, a school that is cited on an acre of land will have more space than another cited on two plots of land. While it is possible for us to ride within some schools, you hardly trek within some and concluded that the more spacious a school, the more healthy are the students" (p. 86)

Equally important, is the establishment of the positive correlation between school plant and students academic performance. Agada(1994), Candill and Olutola (1989) and Umar (1976). Stressing the importance of the library, Luban (1974) asserted that any purposeful education can be achieved through the library in the secondary schools, by the user; certain minimum physical and material requirement must be present. One of which is the space, adequate library space for a single student to browse and study. Oluchukwu (1998) cited Lipham and Hoec (1974), revealed "that school building shall not only be functional servant of educational programs, but shall also be friendly, attractive and stimulating place to impart a feeling of security and a sense of pride to all whom it serves". Ajayi and Yusuf (2009) asserted that the planning of technical workshops in some of the secondary schools seems to be defective too. Apart from the fact that schools use classroom as ad hoc technical workshops, in some cases, technical workshops are located very close to the classrooms. Some technical workshops are stocky and lack adequate facilities and cross ventilation.

Highlighting recent research on improved efforts that linked the multiple dimension of school improvement from 1990s to 2000s, and sampling school improvement effort that link multiple dimension of school improvement, more recent works than in the previous study are discussed because there is a gap in the literature positing a positive relationship between school climate-(transforming the learning environment through reduced class size - 'space', theme based curricula and newly-developed advisory programs) and increasing school achievement. In a study developed in California - California School Climate and Safety Survey (CSCSS) by Furlong, Morrison, Chung, Bates and Morrison (1997) confirmed that unsafe and inadequate school facilities hinder student academic performance.

Indisputably, because adequate school plant provision remain elusive in most Nigerian schools, it seemed desirable to test its ' positive correlation with standard and quality of educational system - Nwagwu, 1978; Adesina, 1990; Ojedele, 2000). The submission that high levels of students' academic performance may not be guaranteed where instructional space such as classrooms, libraries, technical workshops and laboratories are structurally defective - Mark (2002) and Ajayi (2007), and the assertions of Williams, Persaud, and Turner (2008), which reported that safe and orderly classroom 
environment (aspect of instructional space), School facilities (accessories) were significantly related to students' academic performance in elementary schools in a more realistic situation like this research. Accordingly, in the study to be presented here, we exposed school principals and students to filling of questionnaire that was designed to elicit their real response when they thought they are assisting a colleague whose research would sooner or later be beneficial.

\subsection{Purpose of the study}

The purpose of the study was to find out the relationship between school plant planning and students' academic performance in south west Nigeria secondary schools. The study would find out the levels of school plant and students academic performance. It would also find out whether students`academic performance was significantly related to instructional space planning, administrative space planning, circulation space planning, space for convenience planning and accessories planning.

Research Hypotheses:

(i) There is no significant relationship between instructional space planning and students`academic performance.

(ii) There is no significant relationship between administrative space planning and students' academic performance.

(iii) There is no significant relationship between circulation space planning and students' academic performance.

(iv) There is no significant relationship between space for convenience and students' academic performance.

(v) There is no significant relationship between accessories planning and students' academic performance.

\section{Methodology}

\subsection{Study area}

Nigeria is the single largest geographical unit in West Africa. It occupies a land area of 923,768 square kilometers situated between longitude $3^{0}$ and $15^{\circ}$ East, and latitude $4^{0}$ and $14^{0}$ North (CBN, 2000). She lies entirely within the tropics with the two main vegetation zones. The rain forest and savanna zones, reflecting the amount of rainfall and its spatial distribution. The wet and dry seasons are climatically the two major seasons in the country. Nigeria is a conglomerate of several ethnic groups, with three major dominant tribes -Hausa, Ibo and Yoruba domiciled in the North, Southeast and Southwest of the country respectively. About 250 ethnic groups could be recognized in within the country.

A descriptive research of the survey design was used in the study. The population of the study comprised of all secondary schools in south west Nigeria. A total of 1650 respondents consisting of 150 school principals and 1500 students formed the sample of the study. Multi stage, stratified and simple random sampling techniques were used to select the sample. Self developed instruments tagged School Plant Planning Questionnaire (SPPQ) and Students Academic Performance Inventory (SAPI) were used to collect data for the study. The developed (SPPQ) and Students Academic Inventory (SAPI) were administered in fifty secondary schools throughout the Southwest states and majorly in dual secondary schools where we have a combination of Junior Secondary school combined with Senior secondary school within same compound. The participants were told that the research is meant to find a lasting solution to continuous failure of students at the SSCE examination as a result or consequent of school plant planning inadequacies. A Likert scale format was used for SPPQ while a True or False method was used for Students Academic Performance Inventory (SAPI) and the students were also allowed to respond directly to questions asked without any interference from the researcher. For example, Item 6, section 2 of the Inventory stated "I have never repeated a class". In all the five states used for the study, students in Junior Secondary School 3, Senior Secondary School 1 and Senior Secondary School 2 were used. This is to allow those that have acclimatized and have stayed for at least two years respond to questionnaire while the Senior Secondary School 3 was allowed to prepare for their final examination (SSCE). The data which were collected and collated in 2009 were analyzed using frequency counts, percentages and Pearson product moment correlation. The formulated hypotheses were tested at 0.05 level of significance.

\subsection{Analysis of the data}

\section{Students' academic performance level}

The results of the data analysis are presented on the level of students academic performance, respondents to section B of SAPI was used. Frequency counts and percentage score were used to analyze the responses on items of section of SAPI. In order to determine the level of students' academic performance as low, moderate and high, the mean score and standard deviation of the responses were used. The low level of students` academic performance was determined by subtracting the standard deviation from the mean score (73.2-14.1=59.1), Moderate level deviation score of students' academic performance was determined by adding the mean score to the standard deviation score $(73.2+14.1=87.3)$. 
However, the low level of students' academic performance starts from 0-59.1, moderate of students' academic performance starts from 59.2 to 73.2 and high level starts from 73.3 to 100 as in Table 1 below:

$<$ Table 1 about here $>$

$<$ Figure 1 about here $>$

Table 1. indicates the level of school plant planning in south west Nigeria secondary schools. The table reveals that out of 150 schools sampled, 18 representing 12.0 percent had low level of school plant planning while 59 schools representing 39.3 percent had moderate level of school plant planning and 73 schools representing 48.7 percent had high level of school plant planning, this shows that the level of level of school plant planning was relatively high in the schools chosen for the study.

\subsection{School plant planning level}

The results of the data analysis are presented on the school plant planning level of students' academic performance, responses on items of section B of SPPQ was used, frequency count and percentage score were used to analyze the responses on items of section B of SPPQ. In order to rate the level of school plant planning as low, moderate and high. The mean score and standard deviation score of the responses were used. The low level of school plant planning was determined by subtracting the standard deviation from the mean score $(46.9-13.3=33.6)$. Whereas, the moderate level of school plant planning was determined by adding the mean score with standard deviation score $(46.9+13.3=60.2)$. However, it implies that the low level of school plant planning starts from (0-33.6), moderate level of school plant planning starts from (33.7-46.9) while high level of school plan planning starts from (47-100) as displayed in Table 2 below:

$<$ Table 2 about here $>$

$<$ Figure 2 about here $>$

Table 2 shows the level of school plant planning in south west Nigeria secondary schools. The table reveals that out of 150 schools sampled, 26 representing 17.3 percent had low level of school plant planning while 43 schools representing 28.7 had moderate level of school plant planning and 81 schools representing 54 percent had high level of school plant planning, this shows that the level of level of school plant planning was relatively high in the schools chosen for the study.

\subsection{Test of hypotheses}

Table three reflects that school plant planning-instructional space planning, administrative space planning, circulatory space planning, conveniences space planning and accessories planning have positive and significant relationship with students' academic performance. The table shows that there is no significant relationship between accessories planning and students' academic performance; hence, hypotheses 1,2,3,4 were rejected while hypothesis 5 was not rejected. This means that

(i) There is significant relationship between instructional space planning and students`academic performance.

(ii) There is significant relationship between administrative space planning and students` academic performance.

(iii) There is significant relationship between circulation space planning and students' academic performance.

(iv) There is significant relationship between spaces for convenience planning and students`academic performance.

$<$ Table 3 about here $>$

\section{Discussion}

The study revealed that the level of school plant planning in south west Nigeria secondary schools was relatively high as confirmed by this study. The relatively high level of school plant planning might not be unconnected with thorough supervision, control and direction and monitoring of school plant by the Ministry of Education. It is glaring that the relatively high level of school plant planning would enhance better teaching and learning process and facilitates better academic performance. Simply put, Ajayi and Yusuf (2009), "essentially, the main objective of school plant planning is to lay solid foundation for educational structure in order to achieve educational goals and satisfy the physical and emotional needs of the learners and to provide for future expansion of the school system".

Interestingly, it was discovered that the level of students' academic performance in south west Nigeria secondary schools was relatively high during the period under study. The relatively high level of students` academic performance might not be unconnected with the relatively high level of school plant planning among other factors such as motivation of teachers through regular payment of salaries, in-service training and students` commitment to their study. 
The finding of the study supports the researchers cited in the body of the write-up. The study showed that there was significant relationship between school plant planning and students' academic performance. This implies that better school plant planning would enhance better students' academic performance and vice versa. The study revealed further that instructional space like classroom was significantly related to students' academic performance. It is apparent that where classrooms are properly planned in terms of location, structure and facilities, enhanced teaching and learning will take place, thereby leading to better students' academic performance. The finding corroborates that of Agada (1994), Olusola (1989) and Umar (1976) that there is positive correlation between school plant and students' academic performance, hence, they advised that planners should take into consideration students' developmental needs and curriculum in order to make adequate planning, redesigning and expanding and making the classrooms meet the requirements of the students.

The study also revealed that there was significant relationship between administrative and circulatory space planning and students` academic performance. Assisting departments are essential tools in actualization of educational objectives. A school cannot exist without adjunct staff like the Bursar, typists, account clerks, gatemen, kitchen workers and the likes. While the corridors, parks and lanes including other shade apartments in the school offer significant protection to the students hence their contribution to students' academic performance. This corroborates Marsden (2005), Williams, Persuad and Turner (2008), found school facilities were significantly related to students' academic performance in the elementary schools. It was also discovered that there was no significant relationship between accessories planning and students' academic performance. This could be as a result of individual differences and attitude towards game plays, parks, gardens, fields, courts and lawns. Another reason could be the contact hours allotted to games, athletics and others may not be convenient to all student. It is apparent that most students use breaks and game periods for other things they considered cogent. One would expect that if the fields, lawns and parks are maintained, it should translate into good academic performance by the students, but this has been proved wrong by this study.

\section{Conclusion and Recommendations}

This study revealed the importance of school plant planning in the area of instructional space planning, administrative space planning, circulation space planning and convenience space planning. It established that school plant planning directly relates to improved students`academic performance. Based on these findings, it was recommended that efforts should be made by institutional planners to develop in our learners, good planning orientation and program and sustainability culture. Learners that are found to possess the trait should be encouraged through awards and prizes.

Secondly, officials of the inspectorate divisions of State and Federal Ministries of Education should encourage institutional planners, teachers, non-teaching staff and students to be involved in the school plant planning and execution.

Finally, the relative high levels of school plant planning and students' academic performance in the secondary school could be improved upon by school principals, parents and teachers.

\section{References}

Adesina, S. (1990). Educational Management, Enugu: Fourth Dimension Publishing Co Ltd.

Agada, C. N. (1994). School Plant and its Relationship to Pupils`Academic Performance: A case study of Selected Primary Schools in Markurdi LGA of Benue State. Unpublished B.ed Project, University of Jos, Jos.

Ajayi, I. A., \& Yusuf, M. A. (2009). Instructional Space Planning and Students' Academic Performance in Southwest Nigeria Secondary Schools. Int Edu Science, Vol 1 Kamla- Raj. P.73-77

Ajayi, I. A. (1999). Issues in school Management. Lagos; Bola bay Publications.

Ajayi, I. A. (1999). Unit cost of Secondary Education and Students`Academic Achievement in Ondo State (1991-1995). PhD Thesis, Ibadan: University of Ibadan.

Akinbuiro, I. M., \& Joshua, M. T. (2004). Self-concept, Attitude and Achievement of Secondary School Students in Science in Southern Cross Rivers State, Nigeria. The African Symposium, 7(2): 6.

CBN (2000). The Changing structure of the Nigerian Economy and Implications for Development. Lagos: Realm Communication / Central Bank of Nigeria.

Dada, A. (Ed) (1987). Mass Failure in Public Examinations: Causes and Problems; Ibadan; Heinemann Educational Books, Nigeria Ltd.

Duncanson, E., \& Achilles, C. (2008). In Linda K, Lemasters (Ed) the Journal of the International Society for Educational Planning (ISEP) George Washington University, Washington D. C. 
Durosaro, D. O. (1998). School Plant Management Practice in Nigeria: Trends, Issues and Problems, in Olagboye and Fadipe (Eds). Management of Nigeria Education: Project monitoring and School Plant Maintenance. NIEPA, Ondo, Nigeria.

Enaesator, O. (1995). Productivity trends in Secondary Education in Anambra State of Nigeria [1980-1990) in FVM, Onitsha Arinze (Ed): Readings in Nigeria Secondary Education, Nigeria: $\quad$ Hornbill Publishers Ltd.

Furlong, M, J., Morrison, G, M., Chung, A., Bates, M., \& Morrison, R, (1997), School Violence, In G, Baer, K, Minke, \& A, Thomas. (Eds), Children 's Needs 11; Development problems, and alternatives (pp. 245-256), Washington, DC. National Association of School Psychologists

Lubans, J, (1974). Educating the Library User, U.S.A., R: Bowker Company.

Mark, S, (2002). School Building and Students 'Academic Learning Outcomes. Unpublished Manuscript: State university, New York: Stony brook.

Nwagwu, N. A. (1978). Primary School Administration: Lagos, Macmillan Nigeria Publishers Ltd. P.55-66.

Odufowokan, B.A. (2008). Practicum in Classroom Organization and Educational Management, Bosun Publishers Ltd, Ogun-State, Nigeria.

Ojedele, P. K. (2000). Maintaining School Plant for Educational Effectiveness and Efficiency in a depressed Economy. Management of Nigerian Education: Project Monitoring and School Plant Maintenance, NIEPA, Ondo.

Olagboye, A. A. (1998). Promoting School Plant Maintenance Culture in Nigerian School System, Management of Nigerian Education: Project Monitoring and School Plant Maintenance, NIEPA, Ondo.

Oluchukwu (2000). Challenges of Educational Planning in the $21^{\text {st }}$ Century: In Olagboye, A.A. Fadipe, J.O. (Eds) Management of Nigerian Education: School Project Monitoring and School Plant Maintenance. NIEPA, Ondo.

Olutola, A. D. (1989). Education Facilities and Students `Performance in West African School Certificate Examination, International Journal of Educational Management. Vol.7, p.17-24

Umar, M. D. (1996). The Effects of School Physical Facilities and Location on Academic Achievements of Primary School Pupils: Qualitative Study of Ningi LGA of Bauchi State, Unpublished Med Thesis, University of Jos, Jos.

UNESCO (1982). Accommodation and Space for Secondary General Schools: Modules 1, 11, 111 and 1V. Paris: UNESCO.

Williams, E., Persaud, G, \& Turner, T. (2008). in Linda, K. Lemasters (Ed). International Society for Educational Planning (ISEP). George Washington University, Washington D.C.

Yusuf, M.A. (2001). Correlates of Students `Academic Performance in Ekiti State Secondary Schools, Med, Thesis, Unpublished, University of Ado-Ekiti, Nigeria.

Table 1. Level of students' academic performance in south west Nigeria secondary schools

\begin{tabular}{|c|c|c|}
\hline Students academic performance & Frequent counts & Relative percentage \\
\hline Low (0-59.1) & 18 & 12.0 \\
\hline Moderate (59.2-73.2) & 59 & 39.3 \\
\hline High (73.3-100) & 73 & 48.7 \\
\hline Total & 150 & 100 \\
\hline
\end{tabular}

Table 2. Level of school plant planning in south west Nigeria secondary schools

\begin{tabular}{|c|c|c|}
\hline School Plant Planning & Frequency counts & Relative percentage \\
\hline Low (0-33.6) & 26 & 17.3 \\
\hline Moderate (33.7-46.9) & 43 & 28.7 \\
\hline High (47-100) & 81 & 54.0 \\
\hline Total & 150 & 100 \\
\hline
\end{tabular}


Table 3. Relationships between school plant planning and students`academic performance

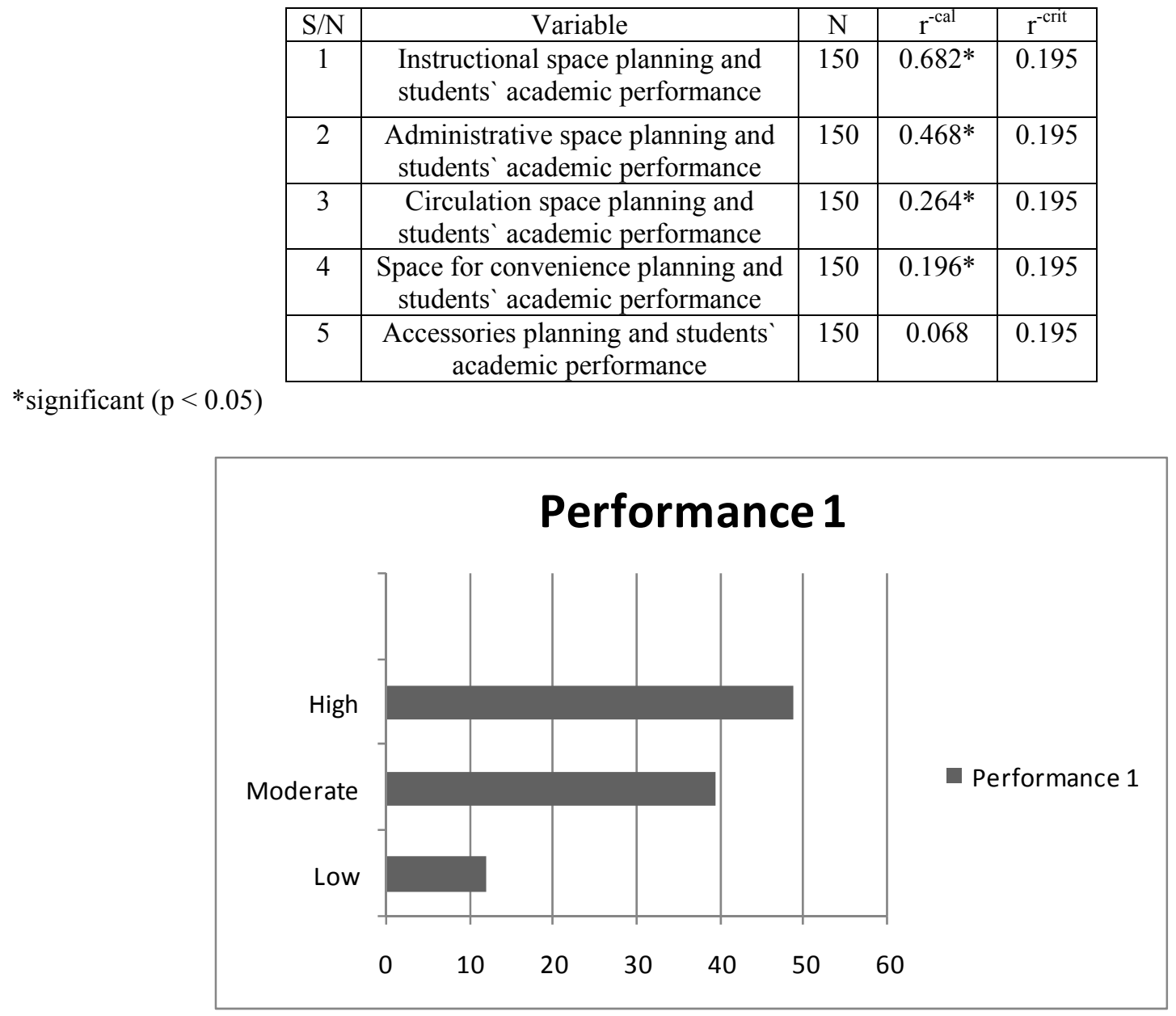

Figure 1. Performance 1

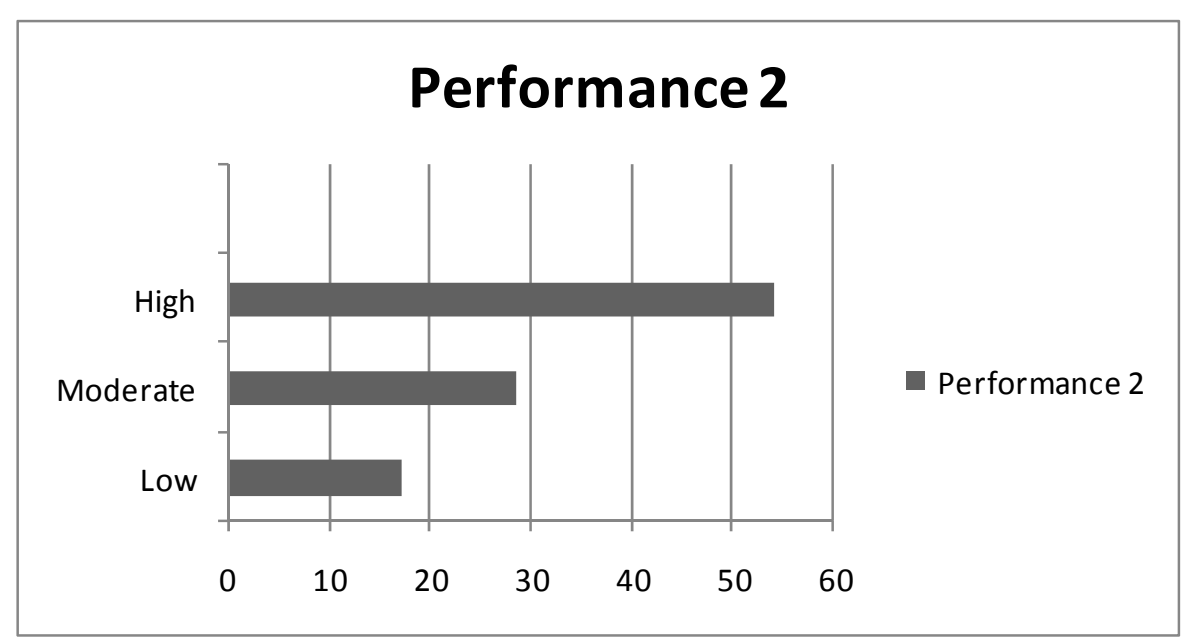

Figure 2. Performance 2 